\title{
Laryngeal Hemorrhage
}

National Cancer Institute

\section{Source}

National Cancer Institute. Laryngeal Hemorrhage. NCI Thesaurus. Code C78411.

Bleeding originating from the larynx. 